\title{
Relationship between Vitamin D Levels and Body Mass Index and Fasting Blood Glucose in Non-Obese Non-Diabetic Women
}

\section{Obez ve Diyabetik Olmayan Kadınlarda Vitamin D Düzeyi ile Beden Kitle Indeksi ve Açlık Kan Şekeri Arasındaki Ilişsi}

\author{
Kadir Serkan Yalçın', (1) Murat Bülent Küçükay², Ali Koşar² \\ 'Department of Internal Medicine, Lokman Hekim University Faculty of Medicine, Ankara, Turkey \\ 2Division of Hematology, Department of Internal Medicine, Lokman Hekim University, Faculty of Medicine, Ankara, Turkey
}

\begin{abstract}
Introduction: Obesity is one of the most critical health problems in the world. Obesity is in the etiology of various chronic diseases, thus causes mortality and morbidity. Especially in recent studies, 25 hydroxyvitamin D3 (25-OH D3) deficiency has been associated with many different diseases and became a significant health problem. Although studies are suggesting an association between obesity and $25-\mathrm{OH} \mathrm{D}_{3}$ deficiency, there is no consensus yet. This study investigates the relationship between 25-OH D3 levels and blood glucose level and body mass index in non-obese and non-diabetic women.

Methods: In this study, the data of female patients aged between 18-84 years, who were applied to the internal medicine outpatient clinic between 2016 and 2018 and whose heights and weights were recorded, were retrospectively analyzed. The study included 201 female patients.

Results: There was a negative correlation revealed between vitamin $D$ levels and body mass index $(r=0.222, p<0.01)$. Discussion and Conclusion: According to these results, 25-OH D3 deficiency should be considered in patients with a high body mass index

Keywords: Body Mass Index; Obesity; Vitamin D Deficiency
\end{abstract}

$\mathrm{O}$ besity is one of the leading health problems of the last half-century. Obesity may trigger diabetes and cardiovascular diseases, becoming the most important cause of morbidity and mortality. ${ }^{[1,2]}$ The number of obese individuals has tripled since 1975 all over the world. Currently, 1.9 billion people are overweight, and more than $30 \%$ are obese. ${ }^{[3]}$ Various studies have shown decreased vitamin D levels in obese individuals, but the possible mechanisms have not been fully elucidated. ${ }^{[4,5]}$ However, the relationship between body mass index, waist circumference, blood triglyceride levels, and vitamin $D$ in non-obese patients has gained importance. 
25-hydroxy vitamin $\mathrm{D} 3\left(25-\mathrm{OH} \mathrm{D}_{3}\right)$ is a vitamin whose deficiency is common all over the world and in our country. This vitamin, which is closely related to bone and calcium balance, is also associated with metabolic abnormalities. ${ }^{[6]}$ Vitamin replacement in patients with $25-\mathrm{OH} \mathrm{D}_{3}$ deficiency may cause a decrease in waist circumference, decreased triglyceride and LDL levels, and increased HDL levels. ${ }^{[7-9]}$ Factors affecting 25$\mathrm{OH} \mathrm{D}_{3}$ level include age, nutritional status, exposure to sunlight, and external intake of vitamin D. ${ }^{[10]}$ In addition to these, physical activity also affects blood $25-\mathrm{OH} \mathrm{D}_{3}$ level. ${ }^{[11]}$

This study investigates the relationship between $25-\mathrm{OH} \mathrm{D}_{3}$ levels and blood glucose level and body mass index in nonobese and non-diabetic women.

\section{Materials and Methods}

In this study, the data of female patients aged between 1884 years, who were applied to the internal medicine outpatient clinic between 2016 and 2018 and whose heights and weights were recorded, were retrospectively analyzed. A total of 201 female patients were included in the study. The ethics committee of Lokman Hekim University University approved this study with decision number $46 / 2019$. All patients included in the study simultaneously had provided fasting blood glucose, 25-hydroxy vitamin $\mathrm{D}_{3}$ levels, hemoglobin levels, vitamin B12 levels, free T3, Free T4 and TSH levels, alanine aminotransferase (ALT), aspartate aminotransferase (AST) levels for various reasons. Urea and creatinine levels were also recorded. Patients with a body mass index above $30 \mathrm{~kg} / \mathrm{m}^{2}$, fasting blood glucose of $>125 \mathrm{mg} / \mathrm{dl}$ and $\mathrm{HbA} 1 \mathrm{c}$ level $>6.5 \%$, patients under antidiabetic medications, using vitamin $\mathrm{D}$ preparations for any reasons, having thyroid dysfunction, liver dysfunction, or kidney disease were excluded from the study.

\section{Statistical Analyses}

All statistical analyzes were performed using Statistical Package for Social Sciences 20.0 (SPSS) for Windows. Fisher's Exact test calculated the demographic characteristics of the patients included in the study. The Pearson correlation test calculated the correlation between values. Results are given as \pm standard deviation. $\mathrm{P}<0.05$ was considered statistically significant.

\section{Results}

Table 1 shows demographic characteristics and laboratory results of the patients included in the study.

There was a negative correlation between the patients' vitamin $D$ levels and body mass indexes $(r=-0.222, p=0.002)$.
Table 1. Demographic characteristics of the patients

\begin{tabular}{lc}
\hline Feature & Mean \pm SD \\
\hline Age & $52.94 \pm 12.0$ \\
Height $(\mathrm{cm})$ & $159 \pm 3.36$ \\
Weight $(\mathrm{kg})$ & $72.32 \pm 13.2$ \\
Body mass index $\left(\mathrm{kg} / \mathrm{m}^{2}\right)$ & $28.5 \pm 3.2$ \\
Fasting blood glucose $(\mathrm{mg} / \mathrm{dl})$ & $94.2 \pm 17.6$ \\
$25-\mathrm{OH} \mathrm{D}$ & $(\mu \mathrm{g} / \mathrm{L})$ \\
\hline
\end{tabular}

SD: Standard Deviation.

There was a positive correlation between fasting blood glucose and body mass index $(r=0.197 p=0.006)$. There was no significant correlation between fasting blood glucose and $25-\mathrm{OH} \mathrm{D}_{3}$ levels of the patients $(r=-0.024, p=0.741)$.

\section{Discussion}

$25-\mathrm{OH} \mathrm{D}_{3}$ is the main regulator of calcium, phosphorus, and bone metabolism. Vitamin D deficiency is very common in both obese and non-obese populations in our country. In order to increase the $25-\mathrm{OH} \mathrm{D}_{3}$ level to a sufficient level, vitamin replacement is the first and most common treatment plan in primary care. In some studies, the vitamin $D$ dose required to increase $25-\mathrm{OH} \mathrm{D}_{3}$ levels in people with high body mass index was 2-3 times higher than that of the normal-weight population. ${ }^{[12]}$ The reason for this is that vitamin $D$ dissolves in fat and goes to the adipose tissue as a target organ after intake. ${ }^{[13]}$ Even if the person is not obese, the increase in subcutaneous and visceral adipose tissue affects the blood level of the preparations given for the treatment. Various studies have previously shown a negative correlation between the amount of subcutaneous and visceral adipose tissue, body mass index and waist circumference, and vitamin D levels. ${ }^{[14,15]}$ There was a negative correlation between vitamin $D$ level and waist circumference in a study conducted by Eun Young Lee et al. ${ }^{[16]}$ in patients over 65 years of age in Korea. Vitezova et al. ${ }^{[17]}$ found high triglyceride levels and low HDL levels in patients with low vitamin $D$ levels and showed that these patients had a significantly wider waist circumference. In this study, an increase in waist circumference was associated with a significant decrease in $25-\mathrm{OH} \mathrm{D}_{3}$ levels. On the other hand, in a study conducted in Pakistan in 2019, Khan et al. ${ }^{[18]}$ could not detect a significant relationship between body mass index and vitamin D levels.

Studies have shown that $25-\mathrm{OH} \mathrm{D}_{3}$ inhibits adipogenic transcription factors and inhibits fat accumulation. ${ }^{[13]}$ Thus, fat accumulation would be more difficult in people with normal $25-\mathrm{OH} \mathrm{D}_{3}$ levels. However, studies show that $25-\mathrm{OH} \mathrm{D}_{3}$ increases insulin secretion via peroxisome prolif- 
erator-activated receptor delta (PPAR-delta). ${ }^{[19]}$ In parallel with this, it also increases glucose uptake by reducing insulin resistance in skeletal muscle cells. Increased glucose degradation can also be considered a factor in reducing fat accumulation. In addition, $25-\mathrm{OH} \mathrm{D}_{3}$ reduces apoptosis in pancreatic beta cells. ${ }^{[20]}$ Decreased need for food with increasing insulin may be effective in decreasing body mass index. As another mechanism, secondary hyperparathyroidism develops in vitamin $\mathrm{D}$ deficiency. Parathormone increases intracellular calcium in adipocytes, increasing the fatty acid synthesis and lipid storage. ${ }^{[21]}$ Therefore, while $25-\mathrm{OH} \mathrm{D}_{3}$ deficiency causes an increase in body mass index, increased body fat rates cause a decrease in vitamin $D$ levels. Consistent with this result, when $25-\mathrm{OH} \mathrm{D}_{3}$ and calcium replacement was applied to patients with $25-\mathrm{OH}$ $D_{3}$ deficiency, a significant decrease was found in body fat ratio compared to the control group. ${ }^{[22]}$

Lifestyle changes and appropriate diet are the first-line treatments for people with a high body mass index. There was a positive correlation between physical activity and $25-\mathrm{OH} \mathrm{D}_{3}$ levels. ${ }^{[10]}$ Studies show that physical activity has a positive effect on $25-\mathrm{OH} \mathrm{D}_{3}$ levels, especially in studies conducted with women. ${ }^{[23]}$ The fact that bone mineral density also increases with physical activity supports this hypothesis. There are also studies showing that there is a significant increase in bone mineral density with physical activity. ${ }^{[24]} A$ decrease in body mass index is expected with exercise. The increased vitamin $D$ levels in these people are attributable to outdoor physical activity, where people are exposed to more sun. In addition, $25-\mathrm{OH} \mathrm{D}_{3}$ absorption from the intestines increases with exercise, increasing vitamin D levels. ${ }^{[23,25]}$ In both cases, an inverse relationship occurs between body mass index and $25-\mathrm{OH} \mathrm{D}_{3}$ levels. In our study, parallel to these studies, a negative correlation was found between vitamin $\mathrm{D}$ level and body mass index.

In conclusion, there is a negative correlation between vitamin D level and body mass index in this study. Vitamin $D$ deficiency and related symptoms should be questioned in obese patients with a body mass index above $25 \mathrm{~kg} / \mathrm{m}^{2}$.

Peer-review: Externally peer-reviewed.

Authorship Contributions: Concept: KSY, MBK, AK; Design: KSY, MBK, AK; Supervision: KSY, MBK, AK; Data Collection or Processing: KSY, MBK, AK; Analysis or Interpretation: KSY, MBK; Literature Search: KSY, AK; Writing: KSY, MBK, AK; Critical Review: KSY, MBK, AK.

Conflict of Interest: None declared.

Financial Disclosure: The authors declared that this study received no financial support.

\section{References}

1. Obesity: a growing threat to health in China. Lancet 2014;384(9945):716.

2. Plourde B, Sarrazin JF, Nault I, Poirier P. Sudden cardiac death and obesity. Expert Rev Cardiovasc Ther 2014;12(9):1099-110.

3. Word Health Organization. Obesity and overweight. Available at: https://www.who.int/news-room/fact-sheets/detail/obesity-and-overweight. Accessed Jun 1, 2019.

4. Rajakumar K, de las Heras J, Chen TC, Lee S, Holick MF, Arslanian SA. Vitamin D status, adiposity, and lipids in black American and Caucasian children. J Clin Endocrinol Metab 2011;96(5):1560-7.

5. Jorde R, Sneve M, Emaus N, Figenschau Y, Grimnes G. Cross-sectional and longitudinal relation between serum 25-hydroxyvitamin D and body mass index: the Troms $\varnothing$ study. Eur J Nutr 2010;49(7):401-7.

6. Wang H, Chen W, Li D, Yin X, Zhang X, Olsen N, et al. Vitamin D and chronic diseases. Aging Dis 2017;8(3):346-53.

7. Upreti V, Maitri V, Dhull P, Handa A, Prakash MS, Behl A. Effect of oral vitamin $D$ supplementation on glycemic control in patients with type 2 diabetes mellitus with coexisting hypovitaminosis D: A parellel group placebo controlled randomized controlled pilot study. Diabetes Metab Syndr 2018;12:509-12.

8. Tabesh M, Azadbakht L, Faghihimani E, Tabesh M, Esmaillzadeh A. Effects of calcium-vitamin D co-supplementation on metabolic profiles in vitamin $D$ insufficient people with type 2 diabetes: a randomised controlled clinical trial. Diabetologia 2014;57(10):2038-47.

9. Barzegari M, Sarbakhsh P, Mobasseri M, Noshad H, Esfandiari $A$, Khodadadi $B$, et al. The effects of vitamin D supplementation on lipid profiles and oxidative indices among diabetic nephropathy patients with marginal vitamin D status. Diabetes Metab Syndr 2019;13(1):542-7.

10. Kluczynski MA, Lamonte MJ, Mares JA, Wactawski-Wende J, Smith $A W$, Engelman $C D$, et al. Duration of physical activity and serum 25-hydroxyvitamin $D$ status of postmenopausal women. Ann Epidemiol 2011;21(6):440-9.

11. Haghshenas R, Jamshidi Z, Doaei S, Gholamalizadeh M. The effect of a high-intensity interval training on plasma vitamin D level in obese male adolescents. Indian J Endocrinol Metab 2019;23(1):72-5.

12. Holick MF, Binkley NC, Bischoff-Ferrari HA, Gordon CM, Hanley DA, Heaney RP, et al; Endocrine Society. Evaluation, treatment, and prevention of vitamin D deficiency: an Endocrine Society clinical practice guideline. J Clin Endocrinol Metab 2011;96(7):1911-30.

13. Ding C, Gao D, Wilding J, Trayhurn P, Bing C. Vitamin D signalling in adipose tissue. Br J Nutr 2012;108(11):1915-23.

14. González L, Ramos-Trautmann G, Díaz-Luquis GM, Pérez $C M$, Palacios C. Vitamin D status is inversely associated with obesity in a clinic-based sample in Puerto Rico. Nutr Res 2015;35(4):287-93.

15. Greene-Finestone LS, Garriguet D, Brooks S, Langlois K, Whiting SJ. Overweight and obesity are associated with lower vi- 
tamin D status in Canadian children and adolescents. Paediatr Child Health 2017;22(8):438-44.

16. Lee EY, Lee SJ, Kim KM, Yun YM, Song BM, Kim JE, et al. Association of metabolic syndrome and 25-hydroxyvitamin D with cognitive impairment among elderly Koreans. Geriatr Gerontol Int 2017;17(7):1069-75.

17. Vitezova A, Zillikens MC, van Herpt TT, Sijbrands EJ, Hofman A, Uitterlinden AG, et al. Vitamin D status and metabolic syndrome in the elderly: the Rotterdam Study. Eur J Endocrinol 2015;172(3):327-35.

18. Khan AH, Fatima SS, Raheem A, Jafri L. Are serum leptin levels predicted by lipoproteins, vitamin $\mathrm{D}$ and body composition? World J Diabetes 2019;10(4):260-8.

19. Dunlop TW, Väisänen S, Frank C, Molnár F, Sinkkonen L, Carlberg $C$. The human peroxisome proliferator-activated receptor delta gene is a primary target of 1alpha,25-dihydroxyvitamin D3 and its nuclear receptor. J Mol Biol 2005;349(2):248-60.

20. Wolden-Kirk H, Overbergh L, Christesen HT, Brusgaard K, Mathieu C. Vitamin D and diabetes: its importance for beta cell and immune function. Mol Cell Endocrinol 2011;347(12):106-20.

21. Soares MJ, Murhadi LL, Kurpad AV, Chan She Ping-Delfos WL, Piers LS. Mechanistic roles for calcium and vitamin D in the regulation of body weight. Obes Rev 2012;13(7):592-605.

22. Rosenblum JL, Castro VM, Moore CE, Kaplan LM. Calcium and vitamin D supplementation is associated with decreased abdominal visceral adipose tissue in overweight and obese adults. Am J Clin Nutr 2012;95(1):101-8.

23. Maïmoun L, Sultan C. Effect of physical activity on calcium homeostasis and calciotropic hormones: a review. Calcif Tissue Int 2009;85(4):277-86.

24. Zittermann A, Sabatschus O, Jantzen S, Platen P, Danz A, Dimitriou $T$, et al. Exercise-trained young men have higher calcium absorption rates and plasma calcitriol levels compared with agematched sedentary controls. Calcif Tissue Int 2000;67(3):215-9.

25. Nelson ME, Meredith CN, Dawson-Hughes B, Evans WJ. Hormone and bone mineral status in endurance-trained and sedentary postmenopausal women. J Clin Endocrinol Metab 1988;66(5):927-33. 